\title{
PENINGKATAN KEMAMPUAN GURU DALAM MENGEMBANGKAN RENCANA PELAKSANAAN PEMBELAJARAN (RPP) BERKARAKTER MELALUI SUPERVISI AKADEMIK DENGAN POLA PENDAMPINGAN
}

\author{
Nursilawana \\ SDN 20 Lebong \\ nursilawana2018@gmail.com
}

\begin{abstract}
ABSTRAK
Tujuan penelitian ini untuk mengetahui kemampuan guru dalam mengembangkan Rencana Pelaksanaan Pembelajaran (RPP) berkarakter. Lokasi penelitian adalah SD Negeri 20 Lebong dengan subjek adalah 9 orang guru di SD Negeri 20 Lebong. Penelitian ini merupakan penelitian tindakan sekolah, dilakukan dalam dua siklus. Data kualitatif yang diperoleh dianalisis secara deskriptif dan dikuantitatifkan secara sederhana dalam bentuk \%. Hasil penelitian, guru yang memiliki kemampuan mengembangkan RPP berkarakter untuk setiap siklusnya mengalami peningkatan yaitu, mulai dari katagori baik $37 \%$ meningkat menjadi $79 \%$, guru yang memiliki kemampuan dengan kategori sedang 39\% menurun menjadi 19\%, dan guru yang memiliki kemampuan dengan kategori rendah $24 \%$ menurun menjadi 2\% karena meningkat kemampuannya. Simpulan, pelaksanaan supervisi akademik melalui pendampingan secara individu dan kelompok dengan langkah-langkah sesuai prosedur supervisi akademik dapat meningkatkan kemampuan guru dalam mengembangkan RPP berkarakter.
\end{abstract}

Kata Kunci : Kemampuan Guru, Supervisi Akademik, RPP berkarakter

\section{ABSTRACT}

The research objective was to find out the teachers ability in developing the character based lesson plan. The location of the research was at SD Negeri 20 Lebong with 9 teachers as the subject. It was a classroom action research, conducted in two cycles. The qualitative data were analyzed descriptively and calculated simply in percentage. The result, the teachers ability in developing the character based lesson plan has improved, namely from $37 \%$ in good category to $79 \%$, medium category from $39 \%$ decreased to $19 \%$, and low category $24 \%$ decreased to $2 \%$. In summary, the application of academic supervising individually and in group by appropriate steps can improve the ability of teacher in developing character based lesson plan.

Keywords: Teachers' ability, Academic Supervising, Character Based Lesson Plan 


\section{PENDAHULUAN}

Keberhasilan tujuan pendidikan tidak terlepas peran serta seorang guru. Hamalik (2004) menjelaskan bahwa guru adalah suatu jabatan professional yang memiliki peranan dan kompetensi professional. Sebab guru yang berkompetenakan lebih mampu menciptakan lingkungan belajar yang efektif, menyenangkan dan akan lebih mampu mengelola kelasnya, sehingga belajar para siswanya berada pada tingkat optimal.

Menurut Sudjana (2006), salah satu kompetensi guru yang penting adalah kompetensi perilaku atau performance artinya kemampuan guru dalam berbagai keterampilan atau berperilaku, seperti keterampilan mengajar, membimbing, menilai, menggunakan alat bantu pengajaran, berkomunikasi dengan siswa, keterampilan menyusun persiapan atau perencanaan mengajar. Terkait dengan kompetensi ini, terlihat masih muncul berbagai kendala dimana masih banyak guru yang belum mampu mengembangkan atau menyusun perencanaan pembelajaran.

Dalam rangka mengimplementasikan program pembelajaran yang sudah dituangkan didalam silabus, guru menyusun Rencana Pelaksanaan Pembelajaran(RPP). RPP merupakan pegangan bagi guru dalam melaksanakan pembelajaran baik dikelas, laboratorium atau lapangan untuk setiap Kompetensi dasar. Oleh karena itu, apa yang tertuang didalam RPP memuat hal-hal yang langsung berkait dengan aktivitas pembelajaran dalam upaya pencapaian penguasaan suatu Kompetensi Dasar. Senada dengan pendapat Subijanto (dalam Nana Sujana, 2006) bahwa dalam pelaksanaan supervisi, sebagian besar pengawas satuan pendidikan tidak melakukan supervisi kelas. Namun sebaliknya pengawas satuan pendidikan cenderung melakukan supervisi dalam hal-hal yang berkaitan dengan kelengkapan administrasi proses belajar-mengajar.

Dengan memperhatikan permasalahan dan kenyataan yang ada, sementara ini sebagian besar guru di SD Negeri 20 Lebong Kabupaten Lebong belum banyak yang mampu mengembangkan atau menyusun RPP berkarakter dengan baik. Untuk memecahkan masalah yang telah diuraikan,dalam rumusan masalah yaitu bagaimanakah pelaksanaan supervisi akademik untuk meningkatkan kemampuan guru di SDN 20 Lebong dalam mengembangkan RPP berkarakter pada Semester II Tahun pelajaran 2017/2018. Adapun tujuan dari dilaksanakannya penelitian ini adalah untuk meningkatkan kemampuan guru mengembangkan RPP berkarakter.

Rencana pelaksanaan pembelajaran (RPP) adalah rencana yang menggambarkan prosedur dan pengorganisasian proses pembelajaran untuk mencapai satu kompetensi dasar yang ditetapkan dalam standar isi dan telah dijabarkan dalam silabus (Hamalik, 2006). Lingkup Rencana Pembelajaran paling luas mencakup1(satu) kompetensi dasar yang terdiri atas1(satu) atau beberapa indikator untuk1(satu) kali pertemuan atau lebih. Selanjutnya perencanaan pembelajaran merupakan bagian penting dalam pelaksanaan pendidikan 
disekolah. Melalui perencanaan pembelajaran yang baik, guru akan lebih mudah dalam melaksanakan pembelajaran dan siswa akan lebih terbantu dan mudah dalam belajar.

Perencanaan pembelajaran dikembangkan sesuai dengan kebutuhan dan karakteristik peserta didik, sekolah, matapelajaran, dan sebagainya. RPP Berkarakter berarti Rencana Pelaksanaan Pembelajaran yang dalam penulisannya mencantumkan penanaman nilai-nilai kehidupan bagi peserta didik. Aplikasi penanaman nilai ini akan dilakukan pada proses eksplorasi, elaborasi dan konfirmasi. Contoh nilai yang akan ditanamkan pada mata pelajaran Ilmu Pengetahuan Alam adalah rasa keingintahuan, kemampuan berpikir secara logis, bertanggung jawab, peduli terhadap lingkungan, bergaya hidup sehat, menumbuhkan rasa percaya diri, kemampuan berfikir kritis, kreatif dan inovatif, menanamkan sikap jujur, menghargai keberagaman, meningkatkan disiplin siswa dan menumbuhkan kecintaan terhadap ilmu. Menurut Aunillah (2011)

Pendidikan Karakter adalah sebuah sistem yang menanamkan nilai-nilai karakter pada peserta didik, yang mengandung komponen pengetahuan, kesadaran individu, tekad serta adanya kemauan dan tindakan untuk melaksanakan nilainilai, baik terhadap Tuhan Yang Maha Esa, diri sendiri, sesama manusia, lingkungan maupun bangsa. Berdasarkan uraian diatas dapat ditegaskan bahwa pendidikan karakter merupakan upaya-upaya yang dirancang dan dilaksanakan secara sistematis untuk membantu peserta didik memahami nilai-nilai perilaku manusia yang berhubungan dengan Tuhan Yang Maha Esa, dirisendiri, sesama manusia, lingkungan, dan kebangsaan yang terwujud dalam pikiran, sikap, perasaan, perkataan, dan perbuatan berdasarkan norma-norma agama, hukum, tatakrama, budaya, dan adat istiadat.

Mengacu pada beberapa pendapat diatas maka konsep pendidikan karakter yang di integralkan kedalam RPP idealnya mencakup pengetahuan, keterampilan, dan sikap. Upaya mengintegrasikan pendidikan karakter kedalam pembelajaran dikelas diperlukan peran kepala sekolah melalui pelaksanaan Supervisi Akademik. Menurut Sergiovani dalam Depdiknas (2008), supervisi akademik merupakan serangkaian kegiatan membantu guru mengembangkan kemampuannya mengelola proses pembelajaran, maka menilai unjuk kerja guru dalam mengelola proses pembelajaran merupakan salah satu kegiatan yang tidak bisa dihindarkan prosesnya.

Tujuan supervise akademik adalah membantu guru mengembangkan kemampuannya mencapai tujuan pembelajaran yang dicanangkan bagi muridmuridnya menurut Glickman dalam Depdiknas (2008) dan untuk melaksanakan supervisi akademik secara efektif diperlukan keterampilan konseptual, inter personal dan teknikal. Oleh sebab itu, setiap Kepala sekolah harus memiliki keterampilan teknikal berupa kemampuan menerapkan teknik-teknik supervisi yang tepat dalam melaksanakan supervisi akademik, dimana teknik supervisi akademik terdiri dua macam, yaitu: individual dan kelompok. Teknik supervisi 
individual adalah pelaksanaan supervisi perseorangan terhadap guru. Supervisor disini hanya berhadapan dengan seorang guru. Dari hasil supervisi ini dapat diketahui kualitas pembelajaran guru bersangkutan. Teknik supervisi kelompok adalah satu cara melaksanakan program supervisi yang ditujukan pada dua orang atau lebih. Guru-guru yang akan disupervisi berdasarkan hasil analisis kebutuhan, dan analisis kemampuan kinerja guru, kemudian dikelompokkan berdasarkan kebutuhan guru. Kemudian guru diberikan layanan supervisi sesuai dengan permasalahan atau kebutuhan yang diperlukan.

\section{METODEPENELITIAN}

Penelitian ini dilaksanakan menggunakan rancangan PTS dengan subjek 9 (Sembilan ) orang guru SD Negeri 20 Kecamatan Lebong yang menjadi sekolah tempat tugas peneliti tahun pelajaran 2017/2018 semester II yang terdiri atas 6 orang guru kelas dan 3 orang guru mapel. Data dikumpulkan melalui observasi terhadap dokumen RPP dan Dokumen aktivitas pembelajaran sebagai dampak RPP berkarakter. Data tersebut diolah secara deskriptif dan kuantitatif sederhana dalam bentuk \% (persen).Penelitian ini dilakukan dalam 2 siklus, setiap siklusnya dilakukan melalui tahap perencanaan tindakan, tindakan supervisi, observasi, dan refleksi (Arikunto, 1997), dijelaskan sebagai berikut:

\section{Perencanaan tindakan (planning).}

Perencanaan tindakan yang dilakukan dalam penelitian ini adalah : (a)Pembuatan instrument; (b)Mempersiapkan materi singkat tentang pengertian dan dasar-dasar serta langkah penyusunan RPP berkarakter; (c)Diskusi terbuka dengan subjek penelitian; (d)Mempresentasikan kesimpulan hasil diskusi ; (e) Pengarahan final dari kepala sekolah.

\section{Pelaksanaan tindakan(action)}

Pelaksanan tindakan merupakan implementasi dari perencanaan penelitian yang telah ditetapkan dalam setiapsiklus, yaitu melaksanakan tahapan-tahapan supervisi akademik meliputi: (1) Pendampingan pembuatan RPP berkarakter baik secara individual maupun kelompok; dan (2) Pendampingan terhadap proses pembelajaran sebagai implementasi RPP berkarakter.

\section{Tahap observasi}

Dilakukan oleh kepala sekolah lokasi penelitianterhadap proses pelaksanaan supervise akademik yang dilakukanoleh teman kolaborasi pada saat peneliti melaksanakan tindakan pendampingan baik di saat penyusunan dokumen RPP berkarakter maupun pendampingan terhadap implementasinya. Pelaksanaan observasi dibantu dengan catatan lapangan. Data yang terkumpul diolah dan disajikan secara deskriptif dan dimuat dalam table 1 yang memuat 8 komponen, 
selanjutnya dikuantitatifkan kedalam bentuk \% dan dinyatakan dalam 3 (tiga) kategori, yaitu:

$0-33 \%=$ Kurang
$34-66 \%=$ Sedang
$67-100 \%=$ Baik

\section{Tahap refleksi}

Dilaksanakan setiap akhir siklus dengan mempedomani hasil dari analisis data. Dari tahap ini diperoleh kekuatan dan kelemahan yang selanjutnya dijadikan sebagai bahan untuk merancang rangkaian penelitian pada siklus berikutnya

\section{HASIL PENELITIAN}

Data yang diperoleh dari tindakan pendampingan secara individu dan kelompok dalam penyusunan RPP berkarakter dan pendampingan implementasinya disajikan dalam tabel 1 dan 2 berikut:

Tabel 1

Data Hasil Pendampingan Dalam Pembuatan RPP Berkarakter

\begin{tabular}{|c|c|c|c|c|c|c|}
\hline \multirow[t]{2}{*}{ No } & \multicolumn{3}{|c|}{ Siklus I } & \multicolumn{3}{|c|}{ Siklus II } \\
\hline & $\begin{array}{ll}\text { Aspek } & \text { yang } \\
\text { disupervisi } & \\
\end{array}$ & Tujuan & Pelaksanaan & $\begin{array}{ll}\begin{array}{l}\text { Aspek } \\
\text { disupervisi }\end{array} & \text { yang } \\
\end{array}$ & Tujuan & Pelaksanaan \\
\hline 1 & $\begin{array}{l}\text { Pembuatan } \\
\text { instrument } \\
\text { bersama-sama } \\
\text { dalam kelompok, } \\
\text { dibimbing kepala } \\
\text { sekolah: (1.) } \\
\text { Indikator } \\
\text { tersusunnya RPP } \\
\text { berkarakter yang } \\
\text { sesuai dengan } \\
\text { kriteria BSNP; } \\
\text { (2.) Kendala- } \\
\text { kendala yang } \\
\text { dialami dalam } \\
\text { penyusunan RPP } \\
\text { berkarakter. }\end{array}$ & $\begin{array}{l}\text { Membuat } \\
\text { rancangan } \\
\text { aspek-aspek } \\
\text { minimal untuk } \\
\text { terbentuk nya } \\
\text { RPP } \\
\text { berkarakter } \\
\text { yang } \\
\text { memenuhi } \\
\text { kriteria } \\
\text { kelayakan dan } \\
\text { daftar kendala } \\
\text { pengembangan } \\
\text { RPP } \\
\text { berkarakter. }\end{array}$ & $\begin{array}{l}\text { Secara } \\
\text { berkelom pok } \\
\text { guru } \\
\text { menentap kan } \\
\text { indicator } \\
\text { kelayakan } \\
\text { RPP } \\
\text { berkarakter. }\end{array}$ & $\begin{array}{l}\text { Pemotivasian: } \\
\text { (1) Menyam- } \\
\text { paikan manfaat } \\
\text { yang penting } \\
\text { tentang kom- } \\
\text { petensi guru dalam } \\
\text { mengem-bangkan } \\
\text { RPP berkarakter } \\
\text { bagi guru maupun } \\
\text { siswa; (2) } \\
\text { Menetapkan } \\
\text { standar keung- } \\
\text { gulan yang tinggi; } \\
\text { (3) Memberikan } \\
\text { insentif berupa } \\
\text { lembar peng- } \\
\text { hargaan guru } \\
\text { berkompeten; (4) } \\
\text { Memberikan } \\
\text { ancaman hu-kuman } \\
\text { bagi guru yang } \\
\text { tidak serius } \\
\text { mengiku-ti } \\
\text { program supervisi. }\end{array}$ & $\begin{array}{l}\text { Meningkatkan } \\
\text { dorongan guru } \\
\text { untuk lebih serius } \\
\text { mengikuti } \\
\text { program supervisi } \\
\text { akademis guna } \\
\text { meningkatkan } \\
\text { kompetensi guru } \\
\text { mengembangkan } \\
\text { dan menyusun } \\
\text { RPP berkarakter. }\end{array}$ & $\begin{array}{l}\text { Kepala sekolah } \\
\text { memberikan } \\
\text { ceramah } \\
\text { pemotivasian, } \\
\text { sertifikat } \\
\text { penghargaan guru } \\
\text { berkompeten } \\
\text { dalam } \\
\text { mengembangkan } \\
\text { RPP berkarakter, } \\
\text { dan penilaian } \\
\text { keaktifan guru } \\
\text { serta menyiapkan } \\
\text { daftar hukuman. }\end{array}$ \\
\hline 2 & $\begin{array}{l}\text { Pembuatan } \\
\text { instrument }\end{array}$ & Mengisi data & $\begin{array}{l}\text { Mengisi } \\
\text { lembar }\end{array}$ & $\begin{array}{l}\text { Pembuatan } \\
\text { instrument }\end{array}$ & $\begin{array}{l}\text { Membuat } \\
\text { rancangan aspek- }\end{array}$ & $\begin{array}{l}\text { Secara } \\
\text { berkelompok }\end{array}$ \\
\hline
\end{tabular}




\begin{tabular}{|c|c|c|c|c|c|c|}
\hline & $\begin{array}{l}\text { bersama-sama } \\
\text { dalam kelompok, } \\
\text { dibimbing kepala } \\
\text { sekolah: (1.) } \\
\text { Indikator } \\
\text { tersusunnya RPP } \\
\text { berkarakter yang } \\
\text { sesuai dengan } \\
\text { kriteria BSNP; } \\
\text { (2.) Kendala- } \\
\text { kendala yang } \\
\text { dialami dalam } \\
\text { penyusunan RPP } \\
\text { berkarakter. }\end{array}$ & & $\begin{array}{l}\text { observasi } \\
\text { secara } \\
\text { berkelom-pok }\end{array}$ & $\begin{array}{l}\text { bersama-sama } \\
\text { dalam kelompok, } \\
\text { dibimbing kepala } \\
\text { sekolah: } 1 . \\
\text { Indikator } \\
\text { tersusunnya RPP } \\
\text { berkarakter yang } \\
\text { sesuai dengan } \\
\text { kriteria BSNP; } 2 \text {. } \\
\text { Kendala-kendala } \\
\text { yang dialami dalam } \\
\text { penyusunan RPP } \\
\text { berkarakter. }\end{array}$ & $\begin{array}{l}\text { aspek minimal } \\
\text { untuk } \\
\text { terbentuknya RPP } \\
\text { berkarak-ter yang } \\
\text { memenuhi kriteria } \\
\text { kelayakan dan } \\
\text { daftar kendala } \\
\text { pengembangan } \\
\text { RPP berkarakter. }\end{array}$ & $\begin{array}{l}\text { guru } \\
\text { menetapkan } \\
\text { indikato } \\
\text { rkelayakan RPP } \\
\text { berkarakter. }\end{array}$ \\
\hline 3 & $\begin{array}{l}\text { Ceramah singkat } \\
\text { tentang pengertian } \\
\text { dan dasar-dasar } \\
\text { langkah } \\
\text { penyusunan RPP } \\
\text { berkarakter oleh } \\
\text { kepala sekolah }\end{array}$ & $\begin{array}{l}\text { Memberi kan } \\
\text { konsep dara } \\
\text { tentang RPP } \\
\text { berkarakter } \\
\text { dan cara } \\
\text { penyusunanny } \\
\text { a }\end{array}$ & $\begin{array}{l}\text { Kepala } \\
\text { Sekolah } \\
\text { memberi kan } \\
\text { ceramah satu } \\
\text { arah. }\end{array}$ & $\begin{array}{l}\text { Pengisian } \\
\text { instrument }\end{array}$ & Mengisi data & $\begin{array}{l}\text { Mengisi lembar } \\
\text { observasi secara } \\
\text { berkelompok }\end{array}$ \\
\hline 4 & $\begin{array}{l}\text { Diskusiterbukasec } \\
\text { ara bersama untuk } \\
\text { penyelesai } \\
\text { an masalah- } \\
\text { masalah dalam } \\
\text { instrumen yang } \\
\text { telah diisi guru }\end{array}$ & $\begin{array}{l}\text { Problem } \\
\text { solving antar } \\
\text { guru dengan } \\
\text { pengawas } \\
\text { sekolah } \\
\text { sebagai } \\
\text { moderator dan } \\
\text { nara sumber }\end{array}$ & $\begin{array}{l}\text { Pengawas } \\
\text { Sekolah } \\
\text { berperan } \\
\text { sebagai } \\
\text { moderator } \\
\text { diskusi } \\
\text { terbuka. }\end{array}$ & $\begin{array}{l}\text { Ceramah singkat } \\
\text { tentang model, } \\
\text { metode, dan } \\
\text { strategi } \\
\text { pembelajaran serta } \\
\text { RPP berkarakter } \\
\text { oleh pengawas }\end{array}$ & $\begin{array}{l}\text { Memberikan } \\
\text { konsep dara } \\
\text { tentang model, } \\
\text { metode, strategi } \\
\text { pembelajaran } \\
\text { serta RPP } \\
\text { berkarakter dan } \\
\text { cara } \\
\text { penyusunannya }\end{array}$ & $\begin{array}{l}\text { Pengawas } \\
\text { memberikan } \\
\text { ceramah satu arah. }\end{array}$ \\
\hline 5 & $\begin{array}{l}\text { Perwakilan } \\
\text { kelompok } \\
\text { mempresentase } \\
\text { kan kesimpulan } \\
\text { hasil diskusi }\end{array}$ & $\begin{array}{l}\text { Menunjukkanh } \\
\text { asildiskusi } \\
\text { yang } \\
\text { disepakati }\end{array}$ & $\begin{array}{l}\text {-Guru } \\
\text { perwakilan } \\
\text { kelompok } \\
\text { presentasi } \\
\text { didepan } \\
\text { ruangan } \\
\text { Kepala } \\
\text { sekolah } \\
\text { memberi-kan } \\
\text { bim-bingan } \\
\text { dengan } \\
\text { ceramah } \\
\text { searah. }\end{array}$ & $\begin{array}{l}\text { Diskusi terbuka } \\
\text { tentang kelebihan } \\
\text { dan kekurangan } \\
\text { berbagai model, } \\
\text { metode, dan } \\
\text { strategi } \\
\text { pembalajaran serta } \\
\text { penerapannya } \\
\text { dengan dibimbing } \\
\text { kepala sekolah. }\end{array}$ & $\begin{array}{l}\text { Meningkatkan } \\
\text { kemampuan } \\
\text { akademis guru } \\
\text { dalam model, } \\
\text { metode, dan } \\
\text { strategi } \\
\text { pembelajaran }\end{array}$ & $\begin{array}{l}\text { Kepala sekolah } \\
\text { berperan sebagai } \\
\text { moderator dan } \\
\text { nara sumber } \\
\text { diskusi terbuka. }\end{array}$ \\
\hline 6 & $\begin{array}{l}\text { Pelatihan } \\
\text { pengembangan } \\
\text { RPP berkarakter }\end{array}$ & $\begin{array}{l}\text { Memberi kan } \\
\text { pengalaman } \\
\text { langsung } \\
\text { melalui } \\
\text { pelatihan } \\
\text { penyusunan } \\
\text { RPP } \\
\text { berkarakter }\end{array}$ & $\begin{array}{l}\text { Kepala } \\
\text { sekolah } \\
\text { memberi-kan } \\
\text { bimbingan } \\
\text { dengan } \\
\text { ceramah satu } \\
\text { arah }\end{array}$ & $\begin{array}{l}\text { Diskusi terbuka } \\
\text { secara bersama } \\
\text { untuk penyelesaian } \\
\text { masalah-masalah } \\
\text { dalam instrumen } \\
\text { yang telah diisi } \\
\text { guru }\end{array}$ & $\begin{array}{l}\text { Problem sol- } \\
\text { vingantar guru } \\
\text { dengan kepala } \\
\text { sekolah sebagai } \\
\text { moderator dan } \\
\text { nara sumber }\end{array}$ & $\begin{array}{l}\text { Kepala sekolah } \\
\text { berperan sebagai } \\
\text { moderator } \\
\text { diskusi terbuka. }\end{array}$ \\
\hline 7 & $\begin{array}{l}\text { Evaluasi hasil } \\
\text { pelatihan } \\
\text { disesuaikan } \\
\text { dengan indikator } \\
\text { kelayakan RPP } \\
\text { berkarakter. }\end{array}$ & $\begin{array}{l}\text { Evaluasi hasil } \\
\text { kerja guru } \\
\text { dalam } \\
\text { mengem-bang } \\
\text { kan RPP } \\
\text { berkarakter }\end{array}$ & $\begin{array}{l}\text { Guru secara } \\
\text { individual } \\
\text { berlatih } \\
\text { mengembang } \\
\text { kan RPP } \\
\text { berkarakter }\end{array}$ & $\begin{array}{l}\text { Perwakilan } \\
\text { kelompok } \\
\text { mempresentasi kan } \\
\text { kesimpulan hasil } \\
\text { diskusi }\end{array}$ & $\begin{array}{l}\text { Menunjukkan } \\
\text { hasil diskusi } \\
\text { yang disepakati }\end{array}$ & $\begin{array}{l}\text {-Guru perwakilan } \\
\text { kelompok } \\
\text { presentasi di- } \\
\text { depan ruangan } \\
\text { Kepala sekolah } \\
\text { memberikan }\end{array}$ \\
\hline
\end{tabular}




\begin{tabular}{|c|c|c|c|c|c|c|}
\hline & & & $\begin{array}{l}\text { untuk satu } \\
\text { kompetensi } \\
\text { dasar }\end{array}$ & & & $\begin{array}{l}\text { bimbingan } \\
\text { dengan ceramah } \\
\text { searah. }\end{array}$ \\
\hline 8 & $\begin{array}{l}\text { Kepala Sekolah } \\
\text { memberikan } \\
\text { pengarahan final }\end{array}$ & $\begin{array}{l}\text { Penguatan } \\
\text { konsep } \\
\text { pengembangan } \\
\text { RPP } \\
\text { berkarakter }\end{array}$ & $\begin{array}{l}\text {-Guru dan } \\
\text { kepala } \\
\text { sekolah } \\
\text { secara ber- } \\
\text { sama-sama } \\
\text { mengevaluasi } \\
\text { hasil } \\
\text { pelatihan } \\
\text { dibanding } \\
\text { kan dengan } \\
\text { ketercapai-an } \\
\text { indika-tor } \\
\text { RPP } \\
\text { berkarakter. } \\
\text {-Kepala } \\
\text { sekolah } \\
\text { menunjukkan } \\
\text { hal-hal yang } \\
\text { perlu } \\
\text { diperbaiki } \\
\text { dan hal-hal } \\
\text { yang perlu } \\
\text { dipertahan } \\
\text { kan. }\end{array}$ & $\begin{array}{l}\text { Pelatihan } \\
\text { merumuskan } \\
\text { langkah-langkah } 3 \\
\text { model dan metode } \\
\text { pembelajaran } \\
\text { beserta strategi } \\
\text { pembelajaran } \\
\text { nya. }\end{array}$ & $\begin{array}{l}\text { Memberikan } \\
\text { pengalaman } \\
\text { terkait dengan } \\
\text { mengembang } \\
\text { kan model, } \\
\text { metode, strategi } \\
\text { pembelajaran }\end{array}$ & $\begin{array}{l}\text { Pelatihan secara } \\
\text { berkelompok } \\
\text { menganalisis dan } \\
\text { merumuskan } \\
\text { langkah-langkah } \\
\text { berbagai model, } \\
\text { metode, dan } \\
\text { strategi } \\
\text { pembelajaran. }\end{array}$ \\
\hline 9 & & & & $\begin{array}{l}\text { Pelatihan } \\
\text { menetapkan } \\
\text { karakter-karakter } \\
\text { penting bagi siswa } \\
\text { dan membuatnya } \\
\text { dalam daftar yang } \\
\text { diurutkan } \\
\text { berdasarkan } \\
\text { prioritas, serta } \\
\text { pelatihan } \\
\text { pengembangan } \\
\text { RPP berkarakter }\end{array}$ & $\begin{array}{l}\text { Memberikan } \\
\text { pengalaman } \\
\text { langsung melalui } \\
\text { pelatihan } \\
\text { menetapkan daftar } \\
\text { karakter\& } \\
\text { memasuk-kannya } \\
\text { dalam } \\
\text { penyusunan RPP } \\
\text { berkarakter }\end{array}$ & $\begin{array}{l}\text { Guru secara } \\
\text { individual berlatih } \\
\text { mendaftar } \\
\text { karakter yang } \\
\text { penting, } \\
\text { mengurutkannya } \\
\text { dalam skala } \\
\text { prioritas, dan } \\
\text { mengembang kan } \\
\text { RPP berkarakter } \\
\text { untuk satu KD }\end{array}$ \\
\hline 10 & & & & $\begin{array}{l}\text { Evaluasi hasil } \\
\text { pelatihan } \\
\text { disesuaikan dengan } \\
\text { indikator kelayakan } \\
\text { RPP berkarakter. }\end{array}$ & $\begin{array}{l}\text { Evaluasi hasil } \\
\text { kerja guru dalam } \\
\text { mengembang } \\
\text { kan RPP } \\
\text { berkarakter }\end{array}$ & $\begin{array}{l}\text { Guru dan Kepala } \\
\text { sekolah secara } \\
\text { bersama-sama } \\
\text { mengevaluasi } \\
\text { hasil pelatihan } \\
\text { dibandingkan } \\
\text { dengan } \\
\text { ketercapaian } \\
\text { indikator RPP } \\
\text { berkarakter }\end{array}$ \\
\hline 11 & & & & $\begin{array}{l}\text { Kepala Sekolah } \\
\text { memberikan } \\
\text { pengarahan final }\end{array}$ & $\begin{array}{l}\text { Penguatan konsep } \\
\text { pengembangan } \\
\text { RPP berkarakter }\end{array}$ & $\begin{array}{l}\text { Kepala Sekolah } \\
\text { menunjukkan hal- } \\
\text { hal yang yang } \\
\text { perlu } \\
\text { dipertahankan.perl } \\
\text { u diperbaiki dan } \\
\text { hal-hal yang perlu }\end{array}$ \\
\hline
\end{tabular}


Tabel 2

Kemampuan Guru Dalam Mengimplementasikan RPP Berkarakter

\begin{tabular}{|c|c|c|c|c|c|c|}
\hline \multirow{2}{*}{$\begin{array}{l}\text { Komponen pengembangan } \\
\text { RPP Berkarakter }\end{array}$} & \multicolumn{3}{|c|}{ Siklus 1} & \multicolumn{3}{|c|}{ Siklus 2} \\
\hline & Baik & Sedang & Kurang & Baik & Sedang & Kurang \\
\hline $\begin{array}{lr}\text { Kemampuan } & \text { Menetapkan } \\
\text { Standar } \quad \text { Isi } & \text { (standar } \\
\text { kompetensi, } & \text { kompetensi } \\
\text { dasar, indikator pembelajaran) }\end{array}$ & $76 \%$ & $12 \%$ & $12 \%$ & $100 \%$ & $0 \%$ & $0 \%$ \\
\hline $\begin{array}{l}\text { Kemampuan menetapkan } \\
\text { tujuan pembelajaran dan } \\
\text { materi pembelajaran }\end{array}$ & $65 \%$ & $18 \%$ & $18 \%$ & $94 \%$ & $6 \%$ & $0 \%$ \\
\hline 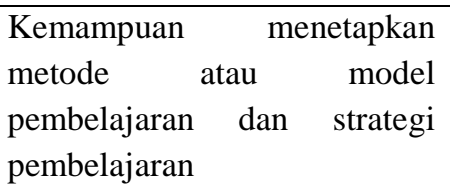 & $18 \%$ & $59 \%$ & $29 \%$ & $65 \%$ & $29 \%$ & $12 \%$ \\
\hline $\begin{array}{l}\text { Kemampuan menetapkan } \\
\text { karakter yang diharapkan }\end{array}$ & $12 \%$ & $53 \%$ & $35 \%$ & $71 \%$ & $24 \%$ & $6 \%$ \\
\hline $\begin{array}{l}\text { Kemampuan mengembangkan } \\
\text { langkah-langkah pembela- } \\
\text { jaran yang relevan dengan } \\
\text { metode / model pembelajaran, } \\
\text { teknik pembelajaran, dan } \\
\text { karakter yang diharapkan } \\
\text { secara sistemik dalam } \\
\text { eksplorasi, elaborasi, dan } \\
\text { konfirmasi. }\end{array}$ & $18 \%$ & $71 \%$ & $12 \%$ & $88 \%$ & $12 \%$ & $0 \%$ \\
\hline $\begin{array}{l}\text { Kemampuan menetapkan } \\
\text { materi }\end{array}$ & $29 \%$ & $47 \%$ & $29 \%$ & $82 \%$ & $18 \%$ & $0 \%$ \\
\hline $\begin{array}{l}\text { Kemampuan menetapkan } \\
\text { kriteria penialaian dalam } \\
\text { produk, performansi. }\end{array}$ & $29 \%$ & $41 \%$ & $29 \%$ & $71 \%$ & $29 \%$ & $0 \%$ \\
\hline $\begin{array}{ll}\text { Kemampuan } & \text { menyusun } \\
\text { lembar penialaian } & \end{array}$ & $53 \%$ & $18 \%$ & $29 \%$ & $65 \%$ & $35 \%$ & $0 \%$ \\
\hline Rata-Rata & $37 \%$ & $39 \%$ & $24 \%$ & $79 \%$ & $19 \%$ & $2 \%$ \\
\hline
\end{tabular}


Tabel3:Peningkatan Kemampuan Guru dalam Menyususn RPP Berkarakter

\begin{tabular}{lll}
\hline $\begin{array}{l}\text { Komponen Pengembangan RPP } \\
\text { berkarakter }\end{array}$ & SiklusI & SiklusII \\
\hline Tinggi & $37 \%$ & $79 \%$ \\
\hline Sedang & $39 \%$ & $19 \%$ \\
\hline Rendah & $24 \%$ & $2 \%$ \\
\hline
\end{tabular}

Berdasarkan data yang disajikan tabel 1, 2 dan 3 dapat dijelaskan bahwa guru-guru dalam mengembangkan RPP setelah mendapat bimbingan singkat secara individu adalah siklus 1 untuk 8 komponen tergolong dalam katagori; (1) Baik dengan perolehan 37\%, (2) Sedang dengan perolehan 39\% dan (3) Kurang dengan perolehan24\%.Sedangkan pada siklus 2 untuk 8 komponen tergolong dalam katagori (1) Baik dengan perolehan79\%, (2)Sedang dengan perolehan $\mathbf{1 9 \%}$ dan (3) Kurang dengan perolehan2\%.

Dari catatan lapangan yang oleh observer selama peneliti melakukan tindakan supervisi akademik terhadap subjek penelitian diperoleh beberapa catatan, yaitu : (1) secara umum peneliti dalam melakukan supervisi sudah sesuai dengan prosedur supervisi; (2) Peneliti sebelum melakukan supervisi sudah mengadakan pertemuan awal dengan subjek supervisi, yang didiskusikan meliputi bagaimana mengembangkan RPP berkarakter; (3) peneliti dalam melaksanakan supervisi tidak bersifat intervensi, (4) guru-guru diberi keleluasaan untuk mencari solusinya sendiri. Hal ini tampak guru-guru subjek merasa enjoy. Sedangkan catatan yang diperoleh observer saat mengobservasi peneliti melaksanakan supervisi akademik terhadap pembelajaran sebagai implementasi RPP yang dikembangkan masih ada 3 (tiga) guru yang belum sepenuhnya mengimplementasikan unsur-unsur hasil pengembangan RPP berkakter yang dibuat. Hal ini disebabkan oleh kurangnya konsep penguatan tentang RPP berkarakter.

Tabel diatas menunjukkan bahwa dalam penelitian ini pelaksanaan supervisi akedemik dapat meningkatkan Kemampuan Guru dalam mengembangkan RPP berarakter dan meningkatkan kualitas implementasinya yaitu dalam bentuk proses pembelajaran. Hal iniditunjukkan dimana jumlah guru yang memiliki kemampuan mengembangkan RPP berkarakter untuk setiap siklusnya mengalami peningkatan yaitu, mulai dari katagori baik 37\% meningkat menjadi 79\%, guru yang memiliki kemampuan dengan kategori sedang 39\% menurun menjadi 19\%, dan guru yang memiliki kemampuan dengan kategori rendah $24 \%$ menurun menjadi $2 \%$ karena meningkat kemampuannya. 


\section{SIMPULAN}

Berdasarkan atas hasil penelitian yang diperoleh, dapat disimpulkan bahwa Pelaksanaan supervisi akademik yang dilaksanakan melalui pendampingan individual dan kelompok dengan langkah-langkah sesuai prosedur dapat meningkatkan kemampuan guru dalam mengembangkan RPP berkarakter dan meningkatkan kemampuan guru mengimplementasikannya dalam proses pembelajaran yang dilakukan.Hal ini ditunjukkan oleh adanya peningkatan hasil dari setiap siklusnya yaitu perolehan kategori "baik" mulai $37 \%$ menjadi $79 \%$.

\section{DAFTARPUSTAKA}

Arikunto. S. (1997). Prosedur Penelitian. Jakarta:RinekaCipta

Aunillah.(2011). Panduan Menerapkan Pendidikan Karakter di Sekolah.Yogyakarta:Laksana

Depdiknas.(2008). Standar Pembangunan Pendidikan Nasional. Jakarta: Depdiknas

Hamalik, O. (2004). Strategi Belajar dan Mengajar. Jakarta: Gramedi Sudjana. (2006).Standar Mutu Pengawas. Jakarta: Depdiknas 